\title{
Enhancement in Cortical Arousal by Caffeine Salicylate in Experimental Animal Models
}

\author{
Shivaji P. Gawade \\ N.B.Chhabada Institute of Pharmacy (Degree), Raigoan, Satara-415020, M.S. India
}

\begin{abstract}
Objective: It is aimed to evaluate contribution of two molecules of Caffeine salicylate, a combinatorial product, in the CNS stimulant, anti-inflammatory and an analgesic property in experimental animal models. Material and Methods: Caffeine salicylate is synthecised by one step reaction from caffeine and salicylic acid. Actophotometer and open field test were used for the CNS stimulant activity whereas formalin induced rat paw edema and tail immersion test were used to evaluate anti-inflammatory and analgesic properties in experimental animals. Results: The locomotor activity was increased from $37.1 \%$ for caffeine to $49.24 \%$ for caffeine salicylate. In open field test; number of crossing and rearing were increased from $42.34 \%$ to $54.89 \%$ and $17.26 \%$ to $27.87 \%$ respectively. The $\%$ inhibition on rat paw edema $16.40 \%$ and $18.75 \%$ with caffeine salicylate as against diclofinac $51.0 \%$ and $62.5 \%$ at 60 and $120 \mathrm{~min}$. respectively. The tail withdrawal time was prolonged by $25 \%$ with caffeine salicylate as against $78.88 \%$ with pentazocine in wistar rats. The results of all experimental animal models were statistically significant. Conclusion: The enhancement in the cortical arousal by caffeine salicylate over caffeine may be due to contribution of antioxidant property of salicylate besides adenosine antagonism and mobilization of intracellular calcium induced dopamine release by caffeine portion of caffeine salicylate. The mild analgesic and anti-inflammatory activities of caffeine salicylate may be due to inhibition of prostaglandin synthesis and an antioxidant properties of salicylate portion of caffeine salicylate.
\end{abstract}

Keywords: Caffeine salicylate, combinatorial, cortical arousal, adenosine, antioxidant.

\section{INTRODUCTION}

Caffeine salicylate is a combinatorial product synthesized from equimolar concentration of caffeine and salicylic acid. The indirect CNS stimulant activity of caffeine is due to the antagonism of adenosine, mobilization of intracellular $\mathrm{Ca}^{2+}$ influencing indirectly the release of dopamine, and inhibition of specific phosphodiesterase at high concentration. Where as salicylate acts by inhibition of synthesis of prostaglandin by inhibiting cycoloxygenase I and by direct activation of AMP activated protein kinase. It is planned in this paper to evaluate CNS stimulant properties of caffeine and mild analgesic and anti-inflammatory activities of salicylates individually and in the combinatorial product caffeine salicylate.

\section{MATERIALS AND METHODS}

\section{Synthesis of Caffeine salicylate}

$5 \mathrm{~g}$ of caffeine and $3.57 \mathrm{~g}$ of salicylic acid was dissolved in $245 \mathrm{ml}$ of dichloromethane. The reaction mixture was heated to boil followed by gentle boiling for about $5 \mathrm{~min}$ utes. The solution was cooled to room temperature. Petroleum ether was added drop wise until the mixture is turned to cloudy. The reaction mixture was cooled slowly to room temperature and then cooled it in ice.

The traces of solvent were removed under vacuum. The weight of the product is 6.106 g i.e. $71 \% \mathrm{w} / \mathrm{w}{ }^{1}$

\section{Locomotor activity}

Locomotor activity was performed using actophotometer according to the method
DOI: 10.5530/ijper.48.3.12

\section{Address for}

correspondence:

Dr. S. P. Gawade

Principal and Director, N.B. Chhabada Institute of Pharmacy (Degree), Raigoan, Satara 415020, M.S. India

E-mail: gneskw@gmail.com

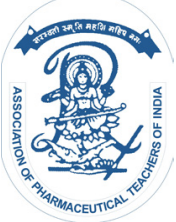

www.ijper.org 
of Dews. ${ }^{2,3}$ Swiss albino male mice weighing between 18-22 g were divided in five groups of six animals each. Group I received normal saline $(0.2 \mathrm{ml} / 20 \mathrm{~g})$. Group II and III received caffeine $(20 \mathrm{mg} / \mathrm{kg}$, p.o.) and Group IV and Group V received caffeine salicylate (34 mg/kg, p.o.). After 30 minutes animals were placed individually in the actophotometer. The movement of animal in terms of series of ambulation that leads to interruptions in the horizontal beam which were recorded as digital counts.

\section{Open Field test}

Open field test was performed according to method described by Hall and Ballachy, ${ }^{4}$ Walsh et.al., ${ }^{5}$ and Brown et.al. ${ }^{6}$ The wistar albino male rats weighing 154-168 gm were divided in three groups of six animals each. Group I received $0.9 \% \mathrm{w} / \mathrm{v} \mathrm{NaCl}(0.2 \mathrm{ml} / 20 \mathrm{gm})$. Group II received Caffeine (20 mg/kg p.o.) and Group III received Caffeine salicylate ( $34 \mathrm{mg} / \mathrm{kg}$, p.o.). Animals were placed individually after 30 minutes in open-field box for rat consisting of 16 squares. The number of line crossing and rearing were recorded manually for $5 \mathrm{~min}$.

\section{Anti-inflammatory activity}

Anti-inflammatory activity was performed using method of formalin induced rat paw edema described by Turner ${ }^{7}$ Lee and Crosby $^{8}$ with suitable medications. Digital water pleythesmometer (Orchid, Nasik) is used to measure small volume changes. The water displacement produced by the immersion of rat paw in the measuring tube of the volume transducer which measures the displacement up to $0.01 \mathrm{ml}$ resolution. The wistar male albino rats of weight range 200-250 g were divided into three groups of six animals each. Group I received normal saline ( $2 \mathrm{ml} / 200 \mathrm{~g}$, p.o.), Group II received standard drug diclofinac (0.9 mg/100 g, s.c.) and group III received caffeine salicylate $(6.1 \mathrm{mg} / 100 \mathrm{~g}$, p.o.). Formalin $(0.1 \mathrm{ml}$ of $1 \% \mathrm{w} / \mathrm{v})$ was injected in the planter region of left paw 30 minutes after the administration of normal saline, diclofinac and caffeine salicylate. The right paws being used as an uninflammed control. The difference in the mean volume between left and right paw is taken as paw volume. Anti-inflammatory activity as \% inhibition in paw volume is calculated as $\%$ inhibition = [1- (Vt-Vo (treated) / Vt-Vo (control)] X 100.

\section{Analgesic activity}

Analgesic activity was performed using tail immersion test according to the method described by Ben Basset et.al. ${ }^{9}$, Gawade. ${ }^{10}$ Male albino rats of weight range 200-225 g were divided into three groups of six animals each. Group I received normal saline $(2 \mathrm{ml} / 200 \mathrm{~g}$, p.o), Group II received pentazocine (20 mg/kg, p.o) and Group III received caffeine salicylate (34 mg/kg, p.o). The temperature of was maintained at $58 \pm 1^{\circ} \mathrm{C}$. The tail of the animal was immersed individually and pain threshold response "tail withdrawal" in seconds with cut off time 10 seconds.

\section{Experimental animals}

Wistar rats and Swiss mice used in the present study, were housed and maintained under standard laboratory conditions in animals house registered by CPCSEA (1314/ac/09/CPCSEA) and were fed with standard pellet diet and water ad libitum. The protocol on experimental animal models were approved by Institutional Animal Ethical Committee.

\section{Statistical analysis}

The data was presented as Mean \pm S.E.M. $(n=6)$. One way ANOVA with post hoc Dunnett test repeated measures ANOVA and paired ' $t$ ' test were used to determine 'p' values using Graph pad Prism software (version 5). $\mathrm{p}<0.05$ is considered as statistically significant.

\section{RESULTS}

Caffeine salicylate was synthecised from caffeine and salicylic acid. The $\%$ yield of caffeine salicylate is $71.6 \% \mathrm{w} / \mathrm{w}$. Caffeine salicylate was characterized for melting point, Rf value on thin layer chromatography and UV spectral analysis for absorbance maximum and wave length. The results of chemical characterization were summarized in Table $1 . \mathrm{LD}_{50}$ of caffeine salicylate by oral route using OECD guidelines 423 was found to be $500 \mathrm{mg} / \mathrm{kg}$.

Table 1: Chemical Characteristics of Caffeine salicylate

\begin{tabular}{|c|c|c|c|c|}
\hline SI.No. & Parameters & Caffeine & Salicylic acid & Caffeine salicylate \\
\hline 01 & Melting point & $226-227^{\circ} \mathrm{C}$ & $158-159^{\circ} \mathrm{C}$ & $143-144^{\circ} \mathrm{C}$ \\
\hline $02(a)$ & $\begin{array}{c}\text { TLC (Rf value) } \\
\text { (Chloroform : } \\
\text { cyclohexane:acetic acid) } \\
(8: 2: 1)\end{array}$ & 0.644 Units & - & 0.55 Units \\
\hline 02(b) & $\begin{array}{c}\text { (Chloroform:cyclohexane) } \\
(9: 1)\end{array}$ & - & 0.25 Units & 0.371 Units \\
\hline 03 & UV spectral analysis & $\begin{array}{c}0.6144 \mathrm{AU} \\
{[\lambda \max : 272.5 \mathrm{~nm}]}\end{array}$ & $\begin{array}{c}0.2598 \mathrm{AU} \\
{[\lambda \max : 296 \mathrm{~nm}]}\end{array}$ & $\begin{array}{c}0.3434 \mathrm{AU} \\
{[\lambda \max : 274.5 \mathrm{~nm}]}\end{array}$ \\
\hline
\end{tabular}


The locomotor activity was increased from 302.33 to $480.67 * * *(37.17 \%)$ for caffeine. The locomotor activity in caffeine salicylate injected mice was significantly higher than that of caffeine. It was increased from 267.67 to $527.33 * *$ (49.24\%). The results of locomotor activity were summarized in Table 2.
The additional locomotor activity was evaluated from parameters line crossing and rearing, using open field test in rats. The number of line crossing were increased from $50.0 \pm 2.24$ to $71.17 \pm 3.83(42.34 \%)$ in animals treated with caffeine. The number of line crossing was higher than that of caffeine in animals treated with caf-

Table 2: Effect of caffeine salicylate on locomotor activity in swiss male mice

\begin{tabular}{|c|c|c|c|c|c|}
\hline SI.No. & Treatment & Dose (p.o.) & \multicolumn{2}{|c|}{ Digital Counts } & $\begin{array}{c}\text { P value } \\
\text { Paired ' } \mathrm{t} \text { ' tes }\end{array}$ \\
\hline & & & Before treatment & After treatment & \\
\hline 1 & Normal saline & $2 \mathrm{ml} / 100 \mathrm{~g}$ & $451.3 \pm 32.67$ & $\begin{array}{c}458.5 \pm 32.38 \\
(1.6 \%)\end{array}$ & \\
\hline 2 & Caffeine & $20 \mathrm{mg} / \mathrm{kg}$ & $380.5 \pm 20.56$ & $\begin{array}{c}513.8 \pm 26.18^{* * *} \\
(35.03 \%)\end{array}$ & $p<0.0001$ \\
\hline 3 & $\begin{array}{l}\text { Caffeine } \\
\text { salicylate }\end{array}$ & $34 \mathrm{mg} / \mathrm{kg}$ & $315.2 \pm 25.86$ & $\begin{array}{c}500.0 \pm 38.99^{* * *} \\
(58.63 \%)\end{array}$ & $P=0.0002$ \\
\hline \multicolumn{5}{|c|}{ One way ANOVA and Post hoc Dunnett test : A/B $\left({ }^{* * *} p\right) ; A / C\left({ }^{* * *} p\right)$} & $p<0.0001$ \\
\hline
\end{tabular}

Values are given as $M \pm \operatorname{SEM}(n=6) . P$ value is determined by paired 't' test and interpreted as ${ }^{*} p<0.05,{ }^{* *} p<0.01,{ }^{* * *} p<0.001$.

feine salicylate. It was increased from $49.5 \pm 2.72$ to $76.67 \pm 4.42(54.89 \%)$. The results of caffeine salicylate using control and standard drug were summarized in Table 3 and were found to be statistically significant. The number of rearing were increased from $149.67 \pm$ 3.1 to $175.5 \pm 3.68(17.26 \%)$ in caffeine treated animals.
The number of rearing was higher than that of caffeine. It was increased from $149.5 \pm 2.6$ to $191.17 \pm 3.07$ $(27.87 \%)$ in animals treated with caffeine salicylate. The results of caffeine salicylate using control and standard drug were summarised in Table 4 and were found to be statistically significant.

\section{Table 3: Effect of caffeine salicylate on 'line crossing' in open field test in rats.}

\begin{tabular}{|c|c|c|c|c|c|}
\hline Sr No. & Treatment & $\begin{array}{c}\text { Dose (mg/kg) } \\
\text { (p.o) }\end{array}$ & Before treatment & After treatment & $\begin{array}{c}\text { P value } \\
\text { [paired 't'test] }\end{array}$ \\
\hline 1 & Normal saline & $10 \mathrm{ml} / \mathrm{kg}$ & $50.83 \pm 3.8$ & $51.33 \pm 2.42$ & \\
\hline 2 & Caffeine & $20 \mathrm{mg} / \mathrm{kg}$ & $50.00 \pm 2.24$ & $\begin{array}{c}71.17^{* * *} \pm 3.33 \\
(42.34 \%)\end{array}$ & $P=0.0005$ \\
\hline 3 & Caffeine salicylate & $34 \mathrm{mg} / \mathrm{kg}$ & $49.50 \pm 2.72$ & $\begin{array}{c}76.67^{* * *} \pm 4.42 \\
(54.89 \%)\end{array}$ & $\mathrm{P}<0.0001$ \\
\hline \multicolumn{5}{|c|}{ One way ANOVA and Post hoc Dunnett test $A / B\left({ }^{* *} p\right) ; A / C\left({ }^{* * *} p\right)$} & ${ }^{* * *} p<0.001$ \\
\hline
\end{tabular}

Values are given as $M+\operatorname{SEM}(n=6)$, Paired t test ${ }^{*} p<0.05,{ }^{* *} p<0.01,{ }^{* * *} p<0.001$

\begin{tabular}{|c|c|c|c|c|c|}
\hline Sr.No. & Treatment & $\begin{array}{c}\text { Dose }(\mathrm{mg} / \mathrm{kg}) \\
\text { [p.o.] }\end{array}$ & Before treatment & After treatment & $\begin{array}{c}\text { p value } \\
\text { [Paired ' } \mathrm{t} \text { ' test }\end{array}$ \\
\hline 1 & Normal saline & $1 \mathrm{ml} / 100 \mathrm{~g}$ & $152.33 \pm 4.8$ & $151.67 \pm 8.34$ & \\
\hline 2 & Caffeine & 20 & $149.67 \pm 3.1$ & $\begin{array}{c}175.5 \pm 3.68^{* * *} \\
(42.34 \%)\end{array}$ & $p<0.0001$ \\
\hline 3 & Caffeine salicylate & 34 & $149.5 \pm 2.6$ & $\begin{array}{c}191.17 \pm 3.07^{\star * *} \\
(54.89 \%)\end{array}$ & $p<0.0001$ \\
\hline
\end{tabular}

Values are given as $M \pm \operatorname{SEM}(n=6)$, paired 't' test ${ }^{*} p<0.05,{ }^{* *} p<0.01,{ }^{, * *} p<0.001$. 
The anti-inflammatory effects of caffeine salicylate were evaluated in comparison with standard anti-inflammatory drug, diclofinac on formalin induced rat paw edema. The time dependent enhancement in the antiinflammatory activity was revealed from increase in the $\%$ inhibition of inflammation with standard diclofinac $51.0 \%$ and $62.5 \%$ and with caffeine salicylate $16.4 \%$ and $18.75 \%$ at $60 \mathrm{~min}$. and $120 \mathrm{~min}$. respectively. The results were summarized in Table 5.

The analgesic effects of caffeine salicylate were evaluated using tail immersion heat conduction method in rats in comparison with standard, Pentazocine. The prolongation in tail withdrawal time from warm water is used as a measure of analgesic activity. The tail withdrawal time was prolonged from $1.61 \pm 0.096$ to 2.88 $\pm 0.14 * * *$ sec. $(78.88 \%)$ with standard pentazocine. Whereas it was prolonged from $1.64 \pm 0.11$ to $2.05 \pm$ $0.12^{* * *}$ sec. $(25.00 \%)$ in caffeine salicylate treated rats. The results were summarized in Table 6.

\section{DISCUSSION}

In the present communication CNS stimulant, analgesic and antinflammatory property of caffeine salicylate and vis a vis contribution of two molecules caffeine and salicylic acid in these activities in a combinatorial product is evaluated using four independent standard methods in experimental animal models. The locomotor and exploratory activity was significantly higher in animals injected with caffeine salicylate as compared to caffeine revealing enhancement in the profound CNS stimulant action of caffeine salicylate. The anti-inflammatory action of sodium salicylate has been reported in the rat. ${ }^{11}$ The mild analgesic activity as shown in tail immersion test in rats may be due to inhibition of synthesis of prostanoid from arachiodonic acid by salicylate component of caffeine salicylate. The mild anti-inflammatory activity of caffeine salicylate may be due to an antioxidant and adenosine release property of salicylate component of caffeine salicylate. ${ }^{12-14}$ The CNS stimulation

Table 5 : Effect of Caffeine salicylate on volume displacement and (\% inhibition) in formalin induced rat paw edema in rats.

\begin{tabular}{|c|c|c|c|c|c|c|}
\hline SI.No. & Treatment & Dose & $\begin{array}{l}0 \min . \\
{[A]}\end{array}$ & $\begin{array}{l}30 \mathrm{~min} . \\
{[B]}\end{array}$ & $\begin{array}{l}60 \min . \\
{[C]}\end{array}$ & $\begin{array}{l}120 \min . \\
{[D]}\end{array}$ \\
\hline 1 & Normal saline & $\begin{array}{l}1 \mathrm{ml} / 100 \mathrm{~g} \\
\text { (p.o) }\end{array}$ & -0.04 & 0.22 & 0.57 & 0.60 \\
\hline 2 & Diclofinac & $\begin{array}{c}0.9 \mathrm{mg} / 100 \mathrm{~g} \\
\text { (s.c.) }\end{array}$ & 0.18 & $0.35(6.0 \%)$ & $\begin{array}{c}0.44^{*} \\
(51.0 \%)\end{array}$ & $\begin{array}{c}0.39 * \\
(62.5 \%)\end{array}$ \\
\hline 3 & $\begin{array}{l}\text { Caffeine } \\
\text { salicylate }\end{array}$ & $\begin{array}{l}6.01 \mathrm{mg} / 100 \mathrm{~g} \\
\text { (p.o) }\end{array}$ & -0.05 & $\begin{array}{c}0.51 \\
(-)\end{array}$ & $\begin{array}{c}0.46^{*} \\
(16.4 \%)\end{array}$ & $\begin{array}{c}0.47^{*} \\
(18.75 \%)\end{array}$ \\
\hline \multicolumn{6}{|c|}{$\begin{array}{l}\text { P value : One way repeated measures ANOVA } \\
\text { Post hoc: Dunnett test } A / B::^{*}(n s), A / C: p<0.05, A / D: p<0.05\end{array}$} & $0.0171^{*}$ \\
\hline
\end{tabular}

\begin{tabular}{|c|c|c|c|c|c|}
\hline \multirow{2}{*}{ SI.No. } & \multirow{2}{*}{ Treatment } & \multirow{2}{*}{$\begin{array}{l}\text { Dose } \mathrm{mg} / \mathrm{kg} \\
\text { (p.o.) }\end{array}$} & \multicolumn{2}{|c|}{$\begin{array}{l}\text { Pain threshold reaction time (see) } \\
\qquad M \pm S E M(n-6)\end{array}$} & \multirow{2}{*}{$\begin{array}{l}\% \text { change in } \\
\text { accordingly }\end{array}$} \\
\hline & & & $\begin{array}{c}\text { Before } \\
\text { treatments }\end{array}$ & $\begin{array}{c}\text { After } \\
\text { treatments }\end{array}$ & \\
\hline 1 & Normal saline & $1 \mathrm{ml} / \mathrm{kg}$ & $1.53 \pm 0.075$ & $1.52 \pm 0.06$ & $0.12 \pm 1.29$ \\
\hline 2 & Pentazocine & 20 & $1.61 \pm 0.096$ & $2.88 \pm 0.14^{* * * *}$ & $44.11 \pm 2.29$ \\
\hline 3 & Caffeine salicylate & 34 & $1.64 \pm 0.11$ & $2.05 \pm 0.12^{* * *}$ & $19.86 \pm 1.17$ \\
\hline \multicolumn{6}{|c|}{ Data is interprected as $\operatorname{M\pm SEM~}(n=6)$} \\
\hline
\end{tabular}

caused by caffeine is indirectly via behavioral arousal. Caffeine by binding to adenosine prevents it from acting on adenosine $A_{2 A}$ receptor to induce inhibitory depressive state. ${ }^{15,16}$ Adenosine is an inhibitory modulator for neuronal excitability, reduce arousal, induce sleep, and suppress spontaneous activity. The antioxidant property of salicylate reduces extracellular level of adenosine. Depression is often associated with calming effect, drowsiness and sleep resembling natural sleep. Adenosine an apparent sleep inducer causes accumulation of ATP. Adenosine by binding to adenosine $A_{2 \mathrm{~A}}$ receptor inhibit cholinergic neurotransmission from central cholinergic neuron of reticular activating system involved in the arousal. Caffeine by binding to adenosine, prevent adenosine from binding to adenosine $A_{2 \mathrm{~A}}$ receptor 
without affecting the acetylcholine releasing action of central cholinergic neuron.

\section{CONCLUSION}

In conclusion caffeine salicylate is synthesized from caffeine and salicylic acid in equimolar proportion by a single step reaction. It is a chance observation that CNS stimulant activity of caffeine salicylate is significantly enhanced than that of caffeine. Besides salicylate component of caffeine salicylate contribute to the additional mild anti-inflammatory and analgesic activity.

\section{ACKNOWLEDGEMENTS}

I wish to acknowledge the research work on Caffeine salicylate of Ms Meera R.Yadav IV B.Pharm project work 2009-2010 and Mr Sachin V.Suryavanshi M.Pharm (II) Pharmacology 2011-2012 carried out under my guidance at Dept. of Pharmacology, Satara College of Pharmacy, Degaon, Satara-415004, M.S., India.

\section{CONFLICT OF INTEREST}

Authors have no conflict of interest to declare.

\section{REFERENCES}

1. Preparation of caffeine salicylate: [cited 2013 March 2]. Available from: URL: Spot.pcc.edu/_candy/241/CaffeineSalicylateLab.pdf; ull.chemistry.uakron. edu/organic lab/cola/caff_eqn.html.

2. Dews PB. The measurement of the influence of drugs on voluntary activity in mice. Brit J Pharmacol. 1953; 8(1): 46-8.
3. Kulkarni SK. Chapter 4, The handbook of Experimental Pharmacology.Delhi: Vallabh Prakashan, Ch.4; 1999. p.117.

4. Hall CS, Ballachay EL. A study on rat's behavior in a field: a contribution to method in a comparative psychology. Univ. of California publications in Psychology. 1932; 6: 11-2.

5. Walsh RN, Cummins RA. The open field test: a critical review. Psychol. Bull. 1976; 83(3): 482-4.

6. Brown RE, Gunn RK, Schellinek HN, Wong AA, O'Leary T. Anxiety exploratory behavior and motor activity in 14 inbred strain of mice. 2004a, MPD:94 Mouse Phenome Database Website,Jackson Laboratory Bar HarborMaine, [cited 2013,July11] Available from http://www.jax.org/phenome.

7. Turner R. Screening method of Pharmacology. Anti-inflammatory agent. Academic press, New York, London. 1965; 13: 158.

8. Lee IO, Crosby G. Halothane effect on formalin induced paw edema and flinching in rats. J. Korean Med. Sci. 1999; 14(1): 34-8.

9. Ben-Basset J, Perete E, Sulman, FG. Analgesiometry and ranking of analgesic drugs by the receptacle method. Arch. Int. Pharmacodyn. 1959; 122: 434-47.

10. Gawade SP. (1995) How's and what's of Pharmacology, 1995; $1^{\text {st }}$ Edition, Nirali Prakashan, Mumbai. Exptl Pharmac.10, p.385.

11. Amman R, Pescara BA. Anti-inflammatory effects of aspirin and sodium salicylate. Eur. J. Pharmacol. 2002; 447(1): 1-9.

12. Suryavanshi SV. Synthesis, characterization and pharmacological studies of caffeine salicylate. M.Pharm. II Pharmacology [dissertation] Shivaji University; 2012.

13. Yadav MR. Caffeine salicylate: Synthesis and preliminary pharmacological study. [project report B.Pharm.VIII Sem.] Shivaji University; 2011.

14. Adenosine pharmacology: Medical news: Adenosine pharmacological effects. [cited on 2013 Jan, 12]. Available from: www.news-medical.net/ health.

15. Yacoubi El, Ledent M, Ledent C, Parmentier C,MCJ, Vanjeoi JM. (2003) Caffeine reduces hypnotic effects of alcohol through adenosine $A_{2 A}$ receptor blockade. Neuropharmacology. 2003; 45: 977-85.

16. Huang L, Qu WH, Egnch N, Chen JF, Schwarz, Schild MA, Fredholm BB, Urade $\mathrm{Y}$, Hayashi $\mathrm{O}$. Adenosine $\mathrm{A}_{2 \mathrm{~A}}$ but not $\mathrm{A}_{1}$ receptors mediate the arousal effect of caffeine. Nat. Neurosci. 2005; 8: 588-9. 